Abstracta Iranica Abstracta Iranica

Revue bibliographique pour le domaine irano-aryen

Volume 29 | 2008

Comptes rendus des publications de 2006

\title{
«Two Recently Discovered Inscribed Sasanian Silver Bowls ». Bulletin of the Asia Institute, 15, 2001 (2005), pp. 71-75, 2 fig.
}

\section{Rémy Boucharlat}

\section{(2) OpenEdition}

1 Journals

\section{Édition électronique}

URL : http://journals.openedition.org/abstractairanica/26522

DOI : 10.4000/abstractairanica.26522

ISSN : 1961-960X

Éditeur :

CNRS (UMR 7528 Mondes iraniens et indiens), Éditions de l'IFRI

\section{Édition imprimée}

Date de publication : 15 mai 2008

ISSN : 0240-8910

\section{Référence électronique}

Rémy Boucharlat, " «Two Recently Discovered Inscribed Sasanian Silver Bowls ». Bulletin of the Asia Institute, 15, 2001 (2005), pp. 71-75, 2 fig. », Abstracta Iranica [En ligne], Volume 29| 2008, document 99, mis en ligne le 15 septembre 2008, consulté le 26 septembre 2020. URL : http:// journals.openedition.org/abstractairanica/26522 ; DOI : https://doi.org/10.4000/abstractairanica. 26522

Ce document a été généré automatiquement le 26 septembre 2020.

Tous droits réservés 


\title{
« Two Recently Discovered
} Inscribed Sasanian Silver Bowls ». Bulletin of the Asia Institute, 15, 2001 (2005), pp. 71-75, 2 fig.

\author{
Rémy Boucharlat
}

Parmi les huit vases en argent du petit trésor de Quri Qaleh, découvert en 1997 sur la route Paveh-Kermanshah, deux de forme elliptique portent une très courte inscription. Sur l'un, décoré d'une grue, 'farroxîh' et 'abzôn', termes bien connus aussi dans la numismatique ; l'autre, décoré d'une pintade, mentionne "plein de graisse ». Ces objets, peut-être cultuels, sont surtout une production d'une élite modeste, sans comparaison avec les grands plats et aiguières sassanides de la table royale.

\section{INDEX}

Thèmes : 3.2.3. Séleucides, Parthes et Sassanides

\section{AUTEURS}

RÉMY BOUCHARLAT

CNRS - Lyon 